\title{
Isolation of Diuron-degrading Bacteria from Treated Soil
}

\author{
Priscila Maria Dellamatrice and Regina Teresa Rosim Monteiro* \\ Centro de Energia Nuclear na Agricultura; C. P. 96; 13400-970; monteiro@ cena.usp.br; Piracicaba - SP - Brazil
}

\begin{abstract}
Studies were carried out on the isolation of diuron-degrading bacteria from treated soil. The mineralization of ${ }^{14} C$ diuron in soil following a three-year application and in soil without previous application were $68.95 \mu \mathrm{g} .100 \mathrm{~g}^{-1}$ and $24.16 \mu \mathrm{g} .100 \mathrm{~g}^{-1}$, respectively, after a 64-day incubation period. In the first soil there was a significant increase in the number of bacteria, from $3.3 \times 10^{6}$ to $1.9 \times 10^{8}$. The microbial biomass did not change, however, a significant ${ }^{14} C$-residue of diuron was found in the microbial biomass. A consortium of three bacteria, Acinetobacter johnsonii and two Bacillus spp., was isolated in medium containing diuron as the only carbon source. Only A. johnsonii was able to grow alone in medium with diuron as the only carbon source.
\end{abstract}

Key words: Biodegradation, biomass, enhanced degradation, diuron, Acinetobacter, bioremediation

\section{INTRODUCTION}

Studies conducted by Cullington and Walker (1999) and Rouchaud et al. (2000) revealed that repeated applications favored the degradation of diuron in soil. According to Dalton et al. (1966), the degradation of diuron begins with the removal of N-methyl groups. Loss of the first methyl group reduces the herbicidal activity to half that of diuron, and loss of the second methyl group eliminates herbicidal activity. Decomposition is followed by the removal of the urea group, which results in the formation of 3,4-dichloroaniline, amonia and $\mathrm{CO}_{2}$. Musumeci et al. (1995) reported 3,4-dichlorophenylmethylurea and 3,4dichlorophenylurea, as products of degradation of diuron formed by hydrolysis of one or two methyl groups from the urea group.

Several microorganisms that degrade diuron have been isolated (Walker and Cullington, 1999; Widehem et al., 2000), but the degradation by these microorganisms resulted in the formation of the 3,4-dichloroaniline. Further degradation of 3,4dichloroaniline by fungi was observed by Widehem et al. (2000) and Tixier et al. (2002) who isolated from soil the Arthrobacter sp. N2 as a diuron-degrader. Isoproturon-degrading bacterium Sphingomonas sp. was also able to mineralize diuron and chlorotoluron, which contain a dimethylurea side chain, such as isoproturon, but not linuron, which contains a methoxy-methyl side chain (Sorensen et al., 2001).

Acinetobacter strains with the ability to metabolise glyphosate as well as aminomethylphosphonate (Chung et al., 1996), diuron (Roque et al., 1998) and diclofop-methyl (Smithgrenier et al., 1996), when added in mineral medium as the only carbon source, have been isolated from heavily polluted streams. Acinetobacter has also been found to degrade several other products like PCBs (Brunner et al., 1985; Furukawa et al., 1983) and phenols (Martins et al., 1997; Hoyle et al., 1995).

The objective of this study was to evaluate the mineralization of ${ }^{14} \mathrm{C}$-diuron in a Brazilian soil

*Author for correspondence 
with and without any application, and to isolate the microorganisms responsible for that.

\section{MATERIAL AND METHODS}

\section{Chemicals \\ ${ }^{14} \mathrm{C}$-U-ring diuron [3-(3,4-dichlorophenyl)-1,1- dimethylurea], which had $96 \%$ radiochemical purity and $2.43 \mathrm{MBq} \cdot \mathrm{mg}^{-1}$ activity, and nonradioactive diuron of $96.4 \%$ purity were used.}

\section{Soil}

The soil samples were collected from the top 10 $\mathrm{cm}$ of a site cultivated with citrus with a three-year history of diuron use and from a nearby site that had never been treated with diuron, where weeds were controlled mechanically. Samples were collected in September 1998, from the Horticulture farm of ESALQ, Piracicaba, SP, Brazil. The soil had $78 \%$ sand, $16 \%$ clay, 18 g.dm ${ }^{3}$ organic matter and a $\mathrm{pH}$ of 4.3 . The soils were sieved $(2 \mathrm{~mm})$ and the moisture was maintained at $75 \%$ of field capacity.

\section{Soil incubation}

The labelled diuron was dissolved in acetone together with nonlabelled diuron to give a concentration of $4 \mu \mathrm{g} \cdot \mathrm{g}^{-1}$ and a radioactivity of 51 $\mathrm{kBq} \cdot 100^{-1} \mathrm{~g}$. Only one diuron application was made and the radioactivity was measured after the application by combustion of the soil samples. Samples of $100 \mathrm{~g}$ of soil without history of diuron application (control) and with three-year history of application were placed in $300 \mathrm{ml}$ Erlenmeyer flasks, in four repetitions. The doses were determined by the specific activity and by HPLC analysis of the soil extracts. The ${ }^{14} \mathrm{CO}_{2}$ was measured using the Anderson method (Anderson, 1990) at 7, 14, 21, 28, 42 and 64 days.

\section{Microbial Evaluation}

The number and microbial biomass were determined at zero time and after 64 days of incubation. Bacteria, fungi and actinomycetes were counted by the spread-plate technique. The media used were nutrient agar, Martin agar and peptone medium. The soil microbial biomass was determined using a fumigation-extraction technique (Vance et al., 1996). For ${ }^{14} \mathrm{C}$ constituents measurements, aliquots of soil extracts were analysed using a Liquid Scintillation Spectrometer (LSS) (Packard Tri-Carb 1.600 TR).

\section{Residues determination}

Soil samples of $25 \mathrm{~g}$ were extracted using agitation with $25 \mathrm{ml}$ of $50 \%$ dichloromethane (v/v) for 30 $\min$ at 120 rev. $\mathrm{min}^{-1}$. The liquid phase was separated by centrifugation at 13000 rev. $\mathrm{min}^{-1}$. The extraction was repeated three times and the radioactivity of the combined supernatant was measured in LSS (Hassink et al., 1994). The soil residues were air-dried overnight and aliquots of 1 $\mathrm{g}$ were analysed for residual radioactivity by combustion analysis, using five repetitions for each treatment, in a Biological Oxidiser (OX500 Harvey Instruments), and the radioactivity was measured by LSS.

\section{Metabolites}

The metabolites were determined by TLC. Dichloromethane solution extracted from soil for residue analyses was applied in Silica Gel plates $60 \mathrm{~F}_{254}$ (Merck) that were developed using dichloromethane/methanol (95:5). The radioactivity was measured using a Berthold TLC analyser.

\section{Isolation of diuron-degraders}

The soil with history of diuron application $(10 \mathrm{~g})$ was suspended in $90 \mathrm{ml}$ of minimal medium

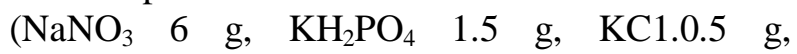
$\mathrm{MgSO}_{4} .7 \mathrm{H}_{2} \mathrm{O} 0.5 \mathrm{~g}, \mathrm{FeSO}_{4}$ and $\mathrm{ZnSO}_{4} 0.0001 \mathrm{~g}$, $1000 \mathrm{ml} \mathrm{H}_{2} \mathrm{O}, \mathrm{pH} \mathrm{6.8)}$. After stirring during 15 min, an aliquot $(1 \mathrm{ml})$ was inoculated into $125 \mathrm{ml}$ Erlenmeyer flasks containing $20 \mathrm{ml}$ of the same medium with diuron at a concentration of $4 \mu \mathrm{g} \mathrm{ml}^{-}$ ${ }^{1}$ as the only carbon source. After incubating for 15 days at $27^{\circ} \mathrm{C}$, aliquots of $1 \mathrm{ml}$ were transferred to fresh medium. The cultures were transferred four times over a two-month period. The microorganisms were isolated after vortexing in Tween 80 solution $0.1 \%$ and streaking in solid medium. Gram reaction and morphology were determined. The purified strains were tested in medium with diuron or 3,4-dichloroaniline as the sole carbon source. The isolated strains were identified through philogenetic analysis of the rDNA $16 \mathrm{~S}$ sequences, by Fundação André Tosello, Campinas, SP, Brazil. 


\section{RESULTS AND DISCUSSION}

Diuron degradation was low in the sample without diuron application, however in the sample with three-year diuron application there was an increase, about seven times, in the degradation of diuron. A lag phase occurred indicating that a period of adaptation was required (Fig 1). Soil samples without diuron application mineralised $15.41 \mu \mathrm{g} .100 \mathrm{~g}^{-1}$ after 28 days and $24.16 \mu \mathrm{g} .100$ $\mathrm{g}^{-1}$ after 64 days of incubation. Soil with diuron application mineralised $36.63 \mu \mathrm{g} .100 \mathrm{~g}^{-1}$ and 68.95 $\mu \mathrm{g} .100 \mathrm{~g}^{-1}$ of the total amount of diuron over the same period of time. The mineralization half-life of diuron was calculated to be 444 days in soil without application and 77 days for soil with application.
After incubating for 64 days, the soil samples without diuron application (control) showed small variation in the number of bacteria, but the number of fungi increased (Table 1). The microbial biomass was the same after the treatment (Table 2). In the soil with diuron application, there was a significant increase in the number of bacteria, from $3.3 \times 10^{6}$ to $1.9 \times 10^{8}$ after the incubation period (Table 1), showing that this group might be the responsible for degradation of diuron in this soil. The microbial biomass also did not change after 64 days (Table 2), but significant ${ }^{14} \mathrm{C}$-residue of diuron was found in the microbial biomass, which might have a role in metabolism and growth. These results are in accordance with the ${ }^{14} \mathrm{CO}_{2}$ production, confirming increase in the mineralization of diuron in the sample with diuron application.

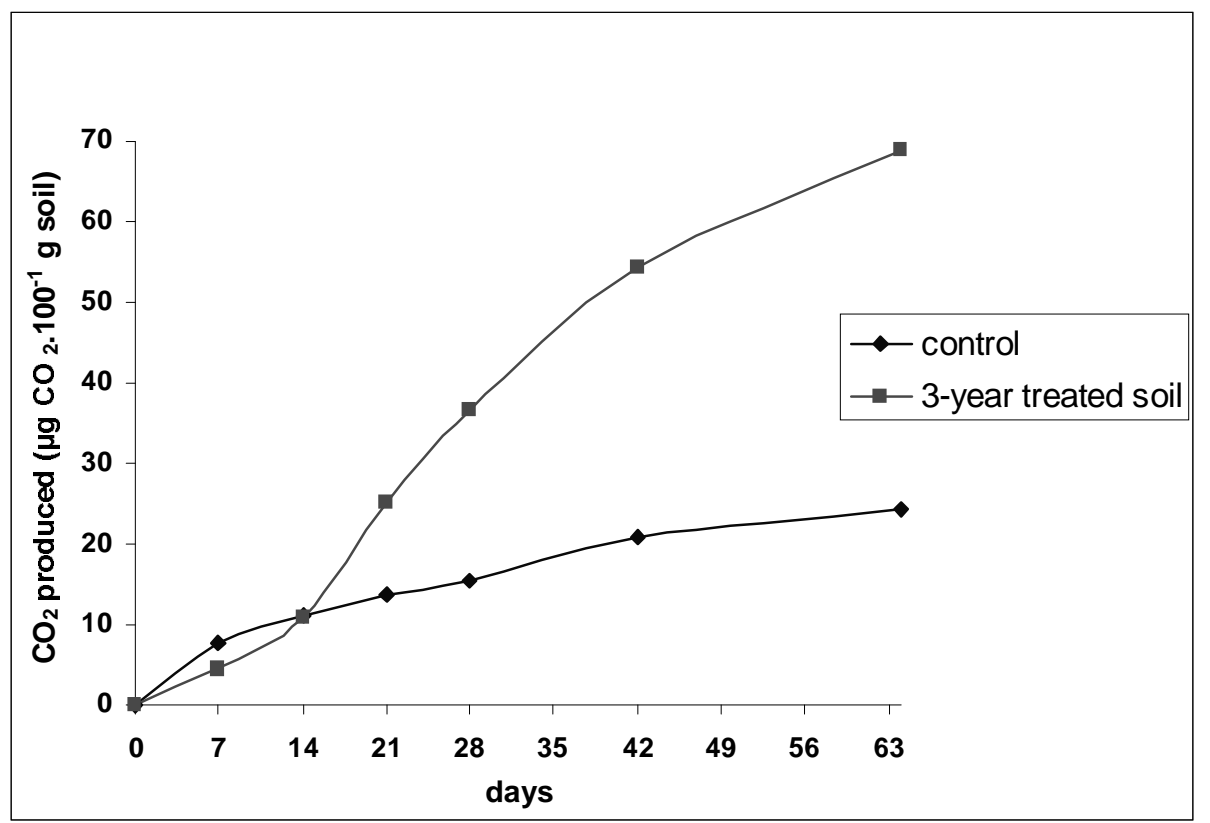

Figure 1 - Production of ${ }^{14} \mathrm{CO}_{2}$ from soil. Control are soil samples with no-history compared with soil samples with three years of diuron-history

Table 1 - Number of microorganisms (UFC. $\mathrm{g}^{-1}$ ) for zero and 64 days of incubation

\begin{tabular}{|c|c|c|c|}
\hline \multirow[b]{2}{*}{ Treatment } & \multicolumn{3}{|c|}{ UFC. g $^{-1}$ soil } \\
\hline & Fungi $\left(\mathbf{x ~ 1 0}^{3}\right)$ & Bacteria $\left(\times 10^{6}\right)$ & Actinomycetes $\left(\times 10^{5}\right)$ \\
\hline & \multicolumn{3}{|c|}{ Day 0} \\
\hline Control & 10 & 10 & 15 \\
\hline \multirow[t]{2}{*}{ Soil treated with diuron } & 9 & 3.3 & 10 \\
\hline & \multicolumn{3}{|c|}{ Day 64} \\
\hline Control & 39 & 8.5 & 8.1 \\
\hline Soil treated with diuron & 66 & 190 & 15 \\
\hline
\end{tabular}


Table 2 - Microbial Biomass and ${ }^{14} \mathrm{C}$-residues of diuron incorporated to microbial biomass for zero and after 64 days of incubation

\begin{tabular}{|c|c|c|}
\hline \multirow[t]{2}{*}{ Treatment } & Biomass-C total & \multirow{2}{*}{$\frac{{ }^{14} \text { C-residues incorporated }}{\mu \mathrm{g} .100 \mathrm{~g}^{-1} \text { soil }}$} \\
\hline & $\mu \mathrm{g} \cdot \mathrm{g}^{-1}$ soil & \\
\hline \multirow{4}{*}{$\begin{array}{l}\text { Control } \\
\text { Soil treated with diuron }\end{array}$} & \multicolumn{2}{|r|}{ Day 0} \\
\hline & $153.08 \mathrm{a}$ & - \\
\hline & $167.63 \mathrm{a}$ & - \\
\hline & \multicolumn{2}{|c|}{ Day 64} \\
\hline Control & $166.81 \mathrm{a}$ & 2.34 \\
\hline Soil treated with diuron & $162.05 \mathrm{a}$ & 17.52 \\
\hline
\end{tabular}

a: values within the same column followed by the same letter are not different at the $5 \%$ level by Tukey's Test

The extractable ${ }^{14} \mathrm{C}$-residues were higher than the unextractable residues in soil without diuron application. In the soil with diuron application, the extractable residues were lower than the unextractable residues showing that the extractable residues were the preferential fraction degraded. These results also showed that the improvements in diuron mineralization were due mainly to the presence of microorganism adapted to diuron.

Only one metabolite was found for both treatments. The values for Rfs were 0.33 for the metabolite and 0.53 for the diuron. The metabolite $\mathrm{Rf}$ was different from the standard $\mathrm{Rf}$ of 3,4dichloroaniline. The soil sample without diuron application had higher amounts of this metabolite (25.69\%) when compared to the sample with diuron $(9.97 \%)$, which indicated that although the mineralization have been $3.93 \%$ in this soil, $25.69 \%$ of diuron was degraded to this unknown metabolite. This suggests that diuron in this sample was degraded by the action of more than one specie of soil microorganism.

A consortium of three kinds of bacteria were isolated in medium containing diuron as the only carbon source. One strain was a gram-negative cocci (strain 1) and the others were gram-positive rods. The rods were separated based on colony morphology: one colony was white opaque with expansive growth that formed branches (strain 2) and the other was white hyaline (strain 3). Strain 1 formed fluorescent blue colony.

Only strain 1 was able to grow alone in the medium containing diuron as the sole carbon source. The others strains were not able to grow without the presence of strain 1 , thus suggesting some kind of association, possibly symbiotic. All three bacteria were not able to grow in medium with 3,4-dichloaniline as the only carbon source, thus showing that this metabolite was not part of the pathway of diuron degradation for these bacteria.

Strain 1 was identified as $A$. johnsonii, strain 2 as Bacilus amyloliquefaciens or $B$. vallismortis (these two strains could not be differentiated by the $16 \mathrm{~S}$ rDNA sequence), and the strain 3 as $B$. subtilis.

\section{CONCLUSIONS}

The mineralization of diuron was higher in a soil with treatment (enhanced degradation) than in soil without any application. Only one bacterium isolated from this soil, A. johnsonii, was capable of using diuron as the sole carbon source. The extractable fraction underwent most of the degradation. The metabolite 3,4-dichloroaniline was not pathway of diuron degradation by this microorganism.

\section{ACKNOWLEDGEMENTS}

The authors would like to thank Dr. Ricardo Victoria Filho for providing access to ESALQHorticulture Farm for soil sample collection. The authors were supported by a personal grant from CNPq.

\section{RESUMO}

A degradação do herbicida diuron foi estudada em solo com e sem histórico de aplicação obtendo-se aproximadamente degradação sete vezes maior no solo com histórico de aplicação, após 64 dias de incubação. Houve um aumento no número de bactérias no solo com histórico de aplicação de 3.3 x $10^{6}$ para 1.9 x $10^{8}$ UFC. $g^{-1}$ solo. Não houve aumento na biomassa após a incubação, porém foi 
encontrado significante resíduo de ${ }^{14} \mathrm{C}$-diuron na biomassa. Um consórcio de três bactérias foi isolado, Acinetobacter johnsonii e duas espécies de Bacillus sp., em meio contendo diuron como única fonte de carbono. Somente A. johnsonnii foi capaz de crescer sozinha em meio contendo diuron como única fonte de carbono.

\section{REFERENCES}

Anderson, J. P. E. (1990), Principles and assay systems for biodegradation. In: Kamely, D.; Chakrabarty, A. and Omenn, G. (Eds.). Biotechnology and biodegradation woodlands: Portfolio. (Advances in Applied Biotechnology, Series 4). pp. 528.

Brunner, W.; Sutherland, F. H. and Focht, D. D. (1985), Enhanced biodegradation of polychlorinated biphenyls in soil by analog enrichment and bacterial inoculation. J. Environm. Qual., 14, 324-328.

Chung, N. J.; Han, H. J.; Lee, H. H.; Rhie, H. G. and Lee, H. S. (1996), Degradation of phosphonate herbicide glyphosate by Acinetobacter Iwoffii HN401. Molecules and Cells, 6, 239-245.

Cullington, J. E. and Walker, A (1999), Rapid biodegradation of diuron and other phenylurea herbicides by a soil bacterium. Soil Biol.Biochem., 31, 677-686.

Dalton, R. L.; Evans, A. W. and Rhodes, R. C. (1966), Disappearance of diuron from cotton field soils. Weeds, 14, 31-33.

Furukawa, K.; Tomizuca, N. and Kamibayashi, A. (1983), Metabolic breakdown of Kaneclors (polychlorobiphenyls) and their products by Acinetobacter sp. Appl. Environ. Microbiol., 46, 140-145.

Hassink, J.; Klein, A.; Kordel, W. and Klein, W. (1994), Behavior of herbicides in non-cultivated soils. Chemosphere, 28, 285-295.

Hoyle, B. L.; Scow, K. M.; Fogg, G. E. and Darby, J. L. (1995), Effect of carbon:nitrogen ratio on kinetics of phenol degradation by Acinetobacter johnsonii in saturated sand. Biodegradation, 6, 283-293.

Martins, J. M.; Jocteur Monrozier, L.; Chalamet, A. and Bardin, R. (1997), Microbial response to repeated applications of low concentrations of pentachlorophenol in an alfisol under pasture. Chemosphere, 35, 1637-1650.

Musumeci, M. R.; Nakagawa, L. E.; Luchini, L. C.; Matallo, M. B. and Andrea, M. M. (1995), Degradação do diuron- ${ }^{14} \mathrm{C}$ em solo e em plantas de cana-de-açúcar (Saccharum spp.). Pesq. Agropec.bras., 30, 775-778.
Roque, M. R. A.; Monteiro, R. T. R.; Ferracini, V. L. and Melo, I. S. (1998) Mineralization of ${ }^{14} \mathrm{C}$-diuron of Acinetobacter baumannii. In: Latin American Biodegradation and Biodeterioration Symposium, 3, Florianópolis. Proceedings... Florianópolis. pp. 5.

Rouchaud, J.; Neus, O.; Bulcke, R.; Cools, K.; Eelen, H. and Dekkers, T. (2000), Soil dissipation of diuron, chlorotoluron, simazine, propyzamide, and diflufenican herbicides after repeated applications in fruit tree orchards. Arch. Environ. Contam. Toxicol., 39, 60-65.

Smithgrenier, L. L. and Adkins, A. (1996), Isolation and characterization of soil microorganisms capable of utilizing the herbicide diclofop-methyl as a sole source of carbon and energy. Can. J. Microbiol., 42, 221-226.

Sorensen, S. R.; Ronen, Z. and Aamand, J. (2001), Isolation from agricultural soil and characterization of a Sphingomonas sp. able to mineralize the phenylurea herbicide isoproturon. Appl. Environ. Microbiol., 67, 5403-5409.

Tixier, C.; Sancelme, M.; Ait-Aissa, S.; Widehem, P.; Bonnemoy, F.; Cuer, A.; Truffaut, N. and Veschambre, H. (2002), Biotransformation of phenylurea herbicides by a soil bacterial strain, Arthrobacter sp. N2: structure, ecotoxicity and fate of diuron metabolite with soil fungi. Chemosphere, 46, 519-526.

Vance, E. D.; Brookes, P. C. and Jenkinson, D. S. (1996), An extraction method for measuring soil microbial biomass C. Soil Biol.Biochem., 19, 703-707.

Walker, A. and Cullington, J. E. (1999), Rapid biodegradation of diuron and other phenylurea herbicides by a soil bacterium. Soil Biol.Biochem., 31, 677-686.

Widehem, P.; Ait-Aissa, S.; Tixier, C.; Sancelme, M.; Veschambre, H. and Truffaut, N. (2000), Isolation, characterization and diuron transformation capacities of a bacterial strain Arthrobacter sp. N2. Chemosphere, 46, 527-534.

Received: March 28, 2003; Revised: January 19, 2004; Accepted: July 02, 2004. 